\title{
Influence of Image And Trust Of Intention To Choosing A University By Word Of Mouth As Moderating Variables
}

\author{
Nugraha Saefudin \\ Faculty of Business and Management \\ Widyatama University \\ Bandung, Indonesia \\ e-mail: nu_sae@yahoo.co.id
}

\begin{abstract}
Public demand on formal education has increased, especially on universities. This has caused universities as strategic sectors that are expected to create a quality human resource. The completion amongst universities tends to increase year to year. This condition demands universities to improve the quality of its education and institution to be excellent in the tight competition. Therefore, this study aims to find out the effect of the trust and the image of universities on student intention using word-of-mouth (wom) as moderating variables. The population of this study is prospective students in Bandung. This study uses deductive quantitative and survey methods. The analytical tool that is used is structural equation modeling (SEM) based on component or a variance that is known as partial least square (PLS) with 135 prospective students in Bandung as respondents . The result of the study shows the positive and significant effect of trust and the image of institutions on students intention. WOM is proved to give a positive and significant effect as a variable that strengthens the relations between the image of universities and student intention and also strengthens the relations between Trust and student intention. This empirical evidence explains that trust and the image of universities are other important factors that can build student intention because students rely on word-of-mouth (WOM) which has a persuasive role in influencing students' decision.
\end{abstract}

\section{Keywords -Image; Trust; Intention; and WOM}

\section{INTRODUCTION}

The number of high school /Islamic High school graduates in 2015 in West Java is 1.62 million, with 60\% (975.000) continue their study to higher education. The number of vocational school graduates is 1.17 million, only $8 \%$ (94.000) who continued to study in higher education.The total number of high school graduates that continued to higher education is around 1.1 million people a year.If the capacity of stateuniversities is 250.000 students per year (2.500 students per university, the 850.000 potential students will be contested by 3.100 private universities (approximately 275 new students per university).

The above data shows the high competition at the higher education sector, especially between private universities in attracting a market of new this tight competition demands a good knowledge and marketing strategy in attracting prospective students from many high schools / vocational schools in Indonesia. Most private universities in Indonesia are facing difficulties in obtaining the numbers of new students and it affects to the universities' survival. On the other hand, prospective students can easily to choose a university that meets their needs. A good quality service of a university is expected to be promoted to other students [1].

Many private universities are offered to prospective students (as customers), they have the freedom to choose a university that can meet or satisfy their expectations. The sampled university in this research is Widyatama University (Universitas Widyatama ) or UTAMA is one of the best universities which promote their excellence in producing compatible graduate as their slogan "Friendly Campus for Future Business Pro".

There are several reasons why customer / prospective students choose a university e.g. the interaction between service provider (universities) with students as the service users, how the environment of higher education institutions affects the students' opinion as users, and how the results of higher education management affect the students'opinion on the service quality provided by the universities.Students who are satisfied with the service will be loyal customers and they will recommend the university to new students if the university has better facilities than other universities.

In addition to the image of the institution, the trust from prospective students to the image of the university is another important factor that builds students intention. Trust as someone's willingness to choose a brand and its risk because there is an expectation that the brand will give them a positive result [2].This means that prospective students trust has an important role in increasing student interest that can be measured by the capability of a university in fulfilling the expectations of prospective students, the services offered, and the nature of the environment that are given to prospective students to have students trust on the university they choose. The integrity between trustees adheres principles which are considered to match the trustor [3]. 
II. Prospective students rely more on word-of-mouth (WOM) in evaluating the services and the quality of education offered by UTAMA because the quality measurement with accreditation assessment and the length of study, the waiting period of the alumni to find a job is not significant. Therefore a new assessing indicator is needed. WOM has a persuasive role in influencing students in making a decision in which students talk positive things (Positive WOM) about the university to other people. A strong positive WOM is expected to influence prospective students to be interested and have an interest to study in that university.

\section{LITERATURE REVIEW}

\subsection{The Effect of University Image on Trust}

The image of University is a brand measurement of higher educations that becomes the characteristic of a university, [4][5] explains that c a company image begins from customers and business players opinions about an organization as the product manufacturer as well as the results of the individual evaluation about it. Companies which have a good image can gain customer trust and interest to buy their products and service [6] This means that a good company image will cause customer trust. Company image gives a positive effect on customer trust [7]

\section{H1:University image has a positive effect on}

\subsection{Effect of Image on Intention}

The aims of a good Company image is to keep a company in business and the people in it continue to develop their creativity and give more benefits to others [8]. Meanwhile, stated that a brand that is known by buyers will influence their interest in making decisions to buy the product/brand.[9] The effect of a symbol of one product gives a meaning in customers' decision making because the symbol and image are important aspects of advertising and have an effect on the customer interest to buy the products.

Brand image affects customers interest in buying a product.[10]. Image influences customer buying intention [11]. The Brand image directly influences the level of customer interest in buying a product [12].

$\mathrm{H} 2$ :University image has a significantly positive effect on the intention of prospective students.

\subsection{Effects of Trust on Student Intention}

Trust is a descriptive notion of a person about something. The Trust will build an image of a brand and a product, people behave in accordance with their belief. [13] Trust as people consider their transactional partner is reliable and honest and have trust in it [14] [15] suggest that trust is the expectation of a cognitive or emotional standpoint.

Trust determines direct and indirect effects on the interest of internet users in buying through e-commerce.[16] Customer trust helps a company in increasing the customer interest in buying their product. [17]. Based on this explanation, customer trust in one brand will arise if the brand meets consumer expectations that will influence customer interest to buy the product.

H3: Trust has a positive and significant impact on student intention.

2.4 Word of Mouth (wom) Moderates The Effect of Trust on Student Intention

Word of mouth is defined as an overall communication from one person to others about a product, service or a company at one time [18]. Word of mouth is the exchange of comments, thoughts, or ideas between two or more consumers, where none of them is a source of marketing [19]

Word-of-mouth is not always communicated face to face [20]. Word of mouth might give a positive or negative effect [21]. A negative word-of-mouth is considered as customer complaints [22], meanwhile, positive word-of-mouth helps a company reducing their marketing cost. Sales and profits can be increased and positive word-of-mouth can attract new customers. Word of mouth has a significant effect on customer buying stage. [23]. Positive word-of-mouth has a moderating effect on the customer trust in buying a product. [24] This means that positive word-of-mouth has an important role to moderate customer decision. Word of mouth has a moderating effect and also consider the effect of trust on student interest in choosing a private university.

Therefore, whom can help prospective students trust in choosing a private university.

H4:Word-of-mouth has a moderating effect on the trust of customers intention in buying a product.

\section{METHODOLOGY}

The population of this research is prospective students or students of High schools in Bandung. The populations of this study are prospective students or students at the high school in Bandung, with 135 students as samples. Survey method and questionnaires are used. A sampling technique that is used is convenience sampling that is a sampling procedure that chooses samples from an individual or unit that are most easily found or accessed [25]

Data analysis Technique that is used is structural equation modeling(SEM) based on component or a variance known as partial least square (PLS).According to Imam Ghozali (2008), partial least square (PLS) is a powerful analytical method that is not based on many assumptions.Data does not have to be a normal distribution and sample size is not necessarily big. There are two relations in partial least square (1) inner model which specify the relations between latent variables or is called structural in covariance SEM. 2) outer model which specifies the relations between latent variables and the indicator, or measuring model in covariance SEM

The variables that are used in this research are university image, trust, WOM, and interest. There are 14 indicators from 4 dimensions to measure the construct of university image, namely: available educational service, nature of the environment, provision of information, behavior and relationships between school communities [27]. Relating to 


\section{Arumers PRESS}

TRUST, who mentioned shared value communication and opportunistic behavior control [28] WOM uses nine indicators from 2 dimensions which are volume and dispersion. According to Schiffman and Kanuk, student interest uses five indicators that are: interested in finding information about products, curiosity about a product, keen to try, consider buying the product and haveing the product [29]

\section{RESULTS}

\subsection{Descriptive Analysis}

The descriptive analysis aims to explain university image, prospective student trust, word of mouth and student interest. The respondent ratings on each variable that is interpreted in respondent average score can be seen in the table.

The interval of respondent's average score is as follows:

Table 4.1 Guidelines Categorization Average Score Respondents

\begin{tabular}{|c|l|}
\hline \multicolumn{1}{|c|}{ Interval } & \multicolumn{1}{c|}{ Category } \\
\hline $1.00-1.79$ & Bad/Very Low/Very Negative \\
\hline $1.80-2.59$ & Quite Bad/Low/Negative \\
\hline $2.60-3.39$ & Average \\
\hline $3.40-4.19$ & Good/High/Positive \\
\hline $4.20-5.00$ & Very Good/Very High/Very Positive \\
\hline
\end{tabular}

\section{University Image}

University trust is measured using 4 indicators. The following is data of average score recapitulation of respondents on four statements about university image.

From table 4.2 the grand mean of respondents score on the variable of university image is 3.21 and it is in the category of average referring to the guidelines in table 4.1.

Table 4.2 Recapitulation Average Score Respondents Regarding Citra College

\begin{tabular}{|c|c|c|c|c|c|c|c|}
\hline \multirow[t]{2}{*}{ Items } & \multicolumn{5}{|c|}{ Score } & \multirow[t]{2}{*}{$\begin{array}{l}\text { Total } \\
\text { Score }\end{array}$} & \multirow[t]{2}{*}{$\begin{array}{l}\text { Mean } \\
\text { Score }\end{array}$} \\
\hline & 5 & 4 & 3 & 2 & 1 & & \\
\hline 1 & 15 & 51 & 23 & 17 & 3 & 385 & 3.53 \\
\hline 2 & 14 & 50 & 22 & 21 & 2 & 380 & 3.49 \\
\hline 3 & 2 & 23 & 18 & 27 & 39 & 249 & 2.28 \\
\hline 4 & 19 & 52 & 20 & 16 & 2 & 397 & 3.64 \\
\hline 5 & 20 & 49 & 17 & 16 & 7 & 386 & 3.54 \\
\hline 6 & 13 & 40 & 17 & 17 & 22 & 332 & 3.05 \\
\hline 7 & 10 & 40 & 15 & 22 & 22 & 321 & 2.94 \\
\hline 8 & 11 & 31 & 11 & 26 & 30 & 294 & 2.70 \\
\hline 9 & 14 & 40 & 26 & 24 & 5 & 361 & 3.31 \\
\hline 10 & 9 & 40 & 14 & 23 & 23 & 316 & 2.90 \\
\hline 11 & 17 & 45 & 36 & 10 & 1 & 394 & 3.61 \\
\hline 12 & 12 & 26 & 13 & 24 & 34 & 285 & 2.61 \\
\hline 13 & 15 & 48 & 30 & 11 & 5 & 384 & 3.52 \\
\hline 14 & 31 & 56 & 3 & 9 & 10 & 416 & 3.82 \\
\hline \multicolumn{7}{|c|}{ Grand Mean } & 3.21 \\
\hline
\end{tabular}

\section{Prospective Student Trust}

The trust of prospective students is measured by three indicators. The data of respondent aveerage score recapitualaton on the three statements about students trust is as follows .

Table 4.3 The recapitulation of respondent average score on prospective students

\begin{tabular}{|c|c|c|c|c|c|c|c|}
\hline \multirow{2}{*}{ Items } & \multicolumn{9}{|c|}{ Score } & Total & $\begin{array}{c}\text { Mean } \\
\text { Score }\end{array}$ \\
\cline { 2 - 8 } & $\mathbf{5}$ & $\mathbf{4}$ & $\mathbf{3}$ & $\mathbf{2}$ & $\mathbf{1}$ & $\begin{array}{c}\text { Score } \\
\text { Score }\end{array}$ & 2.33 \\
\hline 1 & 2 & 12 & 16 & 69 & 10 & 254 & 2.73 \\
\hline 2 & 8 & 17 & 27 & 52 & 5 & 298 & 2.34 \\
\hline 3 & 4 & 11 & 28 & 41 & 25 & 255 & $\mathbf{2 . 4 7}$ \\
\hline
\end{tabular}

Table 4.3 shows the grand mean of respondent total score on prospective student trust is 2.47 and it is in the low categorybased on the guidelines in table 4.1 .

\section{Word of Mouth}

Word of mouth is measured through two indicators. The recapitulation of average respondent score on the two items about word of mouth variable is as follows:

Table 4.4 Recapitulation of Average Respondent Score

\begin{tabular}{|c|c|c|c|c|c|c|c|}
\hline \multirow{2}{*}{ Items } & \multicolumn{5}{|c|}{ Score } & \multirow{2}{*}{$\begin{array}{l}\text { Total } \\
\text { Score }\end{array}$} & \multirow{2}{*}{$\begin{array}{l}\text { Mean } \\
\text { Score }\end{array}$} \\
\hline & 5 & 4 & 3 & 2 & 1 & & \\
\hline 1 & 5 & 29 & 34 & 39 & 2 & 323 & 2.96 \\
\hline 2 & 4 & 41 & 34 & 30 & 0 & 346 & 3.17 \\
\hline 3 & 5 & 44 & 33 & 27 & 0 & 354 & 3.25 \\
\hline 4 & 6 & 40 & 35 & 28 & 0 & 351 & 3.22 \\
\hline 5 & 9 & 40 & 33 & 27 & 0 & 358 & 3.28 \\
\hline 6 & 5 & 43 & 33 & 28 & 0 & 352 & 3.23 \\
\hline 7 & 8 & 43 & 31 & 27 & 0 & 359 & 3.29 \\
\hline 8 & 8 & 31 & 32 & 38 & 0 & 336 & 3.08 \\
\hline 9 & 9 & 42 & 30 & 28 & 0 & 359 & 3.29 \\
\hline \multicolumn{7}{|c|}{ Grand Mean } & 3.20 \\
\hline
\end{tabular}

Based on table 4.4, the grand mean of respondent score on word-of-mouth variable is 3.20 and it is in the average category according to the guidelines on table 4.1

The Intention of Prospective Students

Student interest is measured using five indicators. The recapitulation of average respondents' score of the five statements on the interest of prospective student is described as follows.

Table 4.5 Recapitulation of average respondent score about the intention of prospective students

\begin{tabular}{|c|c|c|c|c|c|c|c|}
\hline \multirow{2}{*}{ Items } & \multicolumn{5}{|c|}{ Score } & \multirow{2}{*}{$\begin{array}{c}\text { Total } \\
\text { Score }\end{array}$} & $\begin{array}{c}\text { Mean } \\
\text { Score }\end{array}$ \\
\cline { 2 - 8 } & $\mathbf{5}$ & $\mathbf{4}$ & $\mathbf{3}$ & $\mathbf{2}$ & $\mathbf{1}$ & 364 & 3.34 \\
\hline 1 & 12 & 49 & 22 & 16 & 10 & 281 & 2.58 \\
\hline 2 & 3 & 29 & 18 & 37 & 22 & 311 & 2.85 \\
\hline 3 & 10 & 29 & 18 & 39 & 13 & \\
\hline
\end{tabular}




\begin{tabular}{|c|c|c|c|c|c|c|c|}
\hline \multirow{2}{*}{ Items } & \multicolumn{5}{|c|}{ Score } & \multirow{2}{*}{$\begin{array}{l}\text { Total } \\
\text { Score }\end{array}$} & \multirow{2}{*}{$\begin{array}{l}\text { Mean } \\
\text { Score } \\
\end{array}$} \\
\hline & 5 & 4 & 3 & 2 & 1 & & \\
\hline 4 & 6 & 36 & 19 & 32 & 16 & 311 & 2.85 \\
\hline 5 & 16 & 53 & 20 & 16 & 4 & 388 & 3.56 \\
\hline \multicolumn{7}{|c|}{ Grand Mean } & 3.04 \\
\hline
\end{tabular}

Table 4.5 shows the grand mean of the respondent score on the variable of the intention of prospective students is 3.04 and it is in the average category referring to the guidelines in table 4.1Furthermore, to test the hypothesis of the study, data is processed by structural equation modeling based on variance.Data processing using partial least square resulted in full model path diagram of the effect of university image on trust and its effect on the trust of prospective students using word-of-mouth as moderating variable described as follows:

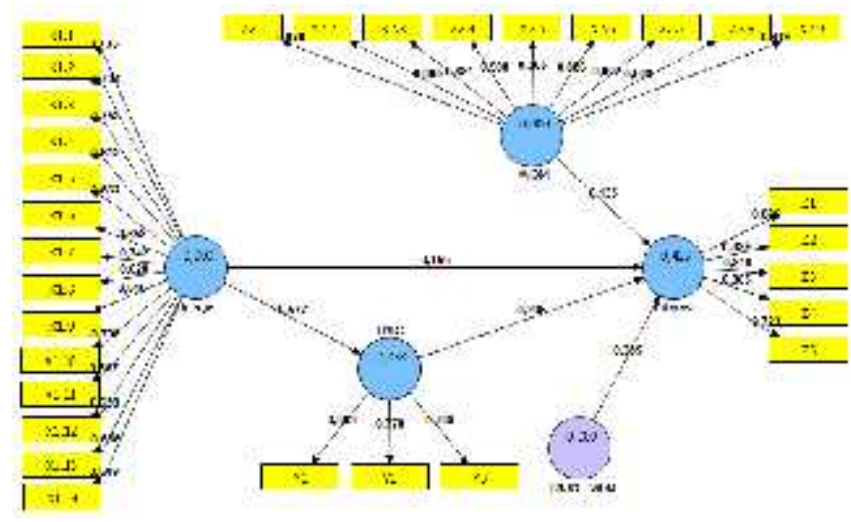

Figure 4.1 Full Model Path Diagram

Through the load factors on figure 4.1 , the validity of each indicator and the reliability of latent variable construct can be measured. An indicator is valid when the load factor is more than 0.50. Composite reliability is considered to be satisfying when it is 0.70 . The result of the testing of measurement model from each latent variable is as follows:

Table 4.6 Summary of the result of Confirmatory Factor Analysis test of each latent variable

\begin{tabular}{clcccc}
\hline $\begin{array}{c}\text { Latent } \\
\text { Variable }\end{array}$ & Iindicator & $\begin{array}{c}\text { Load } \\
\text { Factor }\end{array}$ & $\begin{array}{c}\text { Composite } \\
\text { Relaibility }\end{array}$ & $\begin{array}{c}\text { Variance } \\
\text { Extracted }\end{array}$ & $\begin{array}{c}\text { Cronbac's } \\
\text { Alpha }\end{array}$ \\
\hline $\begin{array}{c}\text { University } \\
\text { Image }\end{array}$ & X.1_1 & 0.735 & 0.920 & 0.906 & 0.452 \\
& X.1_2 & 0.704 & & & \\
& X.1_3 & 0.752 & & \\
& X.1_4 & 0.612 & & \\
& X.1_5 & 0.632 & & \\
& X.1_6 & 0.658 & & \\
& X.1_7 & 0.742 & & \\
X.1_8 & 0.628 & & \\
X.1_9 & 0.616 & & \\
X.1_10 & 0.708 & & \\
X.1_11 & 0.567 &
\end{tabular}

\begin{tabular}{|c|c|c|c|c|c|}
\hline \multirow[t]{4}{*}{$\begin{array}{c}\text { Latent } \\
\text { Variable }\end{array}$} & Iindicator & $\begin{array}{c}\text { Load } \\
\text { Factor }\end{array}$ & $\begin{array}{l}\text { Composite } \\
\text { Relaibility }\end{array}$ & $\begin{array}{c}\text { Variance } \\
\text { Extracted }\end{array}$ & $\begin{array}{c}\text { Cronbac's } \\
\text { Alpha }\end{array}$ \\
\hline & X.1_12 & 0.698 & & & \\
\hline & X.1_13 & 0.686 & & & \\
\hline & X.1_14 & 0.649 & & & \\
\hline \multirow[t]{9}{*}{$\begin{array}{l}\text { Word of } \\
\text { Mouth }\end{array}$} & X.2_1 & 0.670 & 0.958 & 0.950 & 0.718 \\
\hline & X.2_2 & 0.880 & & & \\
\hline & X.2_3 & 0.881 & & & \\
\hline & X.2_4 & 0.908 & & & \\
\hline & X.2_5 & 0.865 & & & \\
\hline & X.2_6 & 0.886 & & & \\
\hline & X.2_7 & 0.902 & & & \\
\hline & X.2_8 & 0.669 & & & \\
\hline & X.2_9 & 0.919 & & & \\
\hline \multirow[t]{3}{*}{ Trust } & Y_1 & 0.883 & 0.858 & 0.752 & 0.669 \\
\hline & Y_2 & 0.778 & & & \\
\hline & Y_3 & 0.789 & & & \\
\hline $\begin{array}{c}\text { Prospective } \\
\text { Student }\end{array}$ & Z_1 & 0.806 & 0.904 & 0.867 & 0.655 \\
\hline \multirow{4}{*}{ Intention } & Z_2 & 0.829 & & & \\
\hline & Z_3 & 0.816 & & & \\
\hline & Z_4 & 0.865 & & & \\
\hline & Z_5 & 0.723 & & & \\
\hline
\end{tabular}


The data in table 4.6 shows that for the university image variable, the load factor of each variable is 0.50 . This means that the 14 indicators are valid in measuring the latent variable of university image. The composite reliability and Cronbach's alpha values are bigger than 0.7 which indicates that the fourteen indicators have consistency in measuring latent variable of university image. Variance extracted is 0.452 which indicates that on average $45.2 \%$ of the information in each indicator can be represented through variable latent of university image. The biggest load factor of the latent variable of university image is an X.1_3 indicator (a sufficient level of HRD). This means that the level of HRD is the highest in reflecting university image.

In latent variable of the word of mouth, the load factor of each indicator is bigger than 0.50. This means that the nine indicators are valid in measuring the latent variable of wordof-mouth. The composite reliability and Cronbach's alpha is bigger than 0.7 indicating that the nine indicators have consistency in measuring word of mouth variable.Variance extracted is 0.718 indicating that on average $71.8 \%$ of the information in each indicator can be represented by a word of mouth variable. The biggest load factor of the word of mouth variable is an X.2_9 indicator (getting information about UTAMA from people who do not study in UTAMA). This means that getting information about UTAMA from those who do not study in UTAMA is stronger in reflecting word of mouth.

In latent variable of the trust of prospective students, the load factor of each indicator is bigger than 0.50 . This indicates that the three indicators are valid in measuring prospective student trust variable. Composite reliability and Cronbach's alpha is bigger than 0.7 indicating that both indicators have consistency in measuring trust variable.Variance extracted 0.669 indicating that on average $66.9 \%$ of the information in each indicator can be represented through trust variable. The biggest load factor of trust variable is Y_1 (shared value) indicator. This means that shared value is the strongest indicator in reflecting the trust of prospective students.

In the latent variable of prospective student interest, the load factor of each indicator is 0.50 . This shows that the five indicators are valid in measuring the interest variable. Composite reliability and Cronbach's alpha are bigger than 0.7 indicating that the five indicators have consistency in measuring latent variable of student interest.Variance extracted 0.655 indicating that in average $65.5 \%$ of the information in each indicator can be represented through interest variable.The biggest load factor of student interest variable is Z-4(consider to study at UTAMA) indicator. This means that the considering to study in UTAMA is the strongest indicator in reflecting prospective students' interest.

\subsection{Hypothesis Testing}

After each measurement model of each latent variable is described. Hypothesis testing is conducted. The summary of hypostasis testing is as follows:
Table 4.7 Summary of Hypothesis Test Result

\begin{tabular}{|l|l|l|r|r|}
\hline $\begin{array}{l}\text { Sub } \\
\text { Structure }\end{array}$ & \multicolumn{1}{|c|}{ Path } & $\begin{array}{l}\text { Path } \\
\text { coefficient }\end{array}$ & tstatisice $^{*}$ & $\mathrm{R}^{2}$ \\
\hline First & Image $\rightarrow$ Trust & 0.577 & 9.639 & 0.333 \\
\hline Second & Image $\rightarrow$ Intention & 0.166 & 1.978 & 0.423 \\
\cline { 2 - 4 } & Trust $\rightarrow$ Intention & 0.205 & 2.287 & \\
\cline { 2 - 4 } & WOM $\rightarrow$ Intention & 0.135 & 1.346 & \\
\cline { 2 - 5 } & $\begin{array}{l}\text { Trust*WOM } \\
\text { Intention }\end{array}$ & 0.385 & 3.467 & \\
\hline
\end{tabular}

Through determination coefficient score (R-square) in Table 4.7, university image has an effect on prospective students as much as $33.3 \%$. The image of university and the trust of prospective students which are moderated by word of mouth give an effect on student intention as much as $42.3 \%$.

\section{CONCLUSION}

5.1 The effect of university image on the trust of prospective students

Based on test results in Table 4.7, statistical university image on prospective-student trust (9.639) is bigger than critical(1.96). This means that university image affects the trust of prospective students. The results of this study provide empirical evidence that a better image of a university will produce greater trust of prospect students.The results are consistent with [30] [31] which have stated that a company image gives a positive effect on customer trust. This means that a good reputation of one company will give a trust from the customers. In this research, a university which has a positive image reflect a good quality educational service and consistency in maintaining their reputation and credibility that make prospective students believe that the private university they have chosen will provide their needs and will ultimately make prospective student trust.

\section{2 Effect of Prospective student Trust on Student Intention}

Based on test results in table 4.7, $\mathrm{t}$ statistic of university image on the interest of prospective students (1.978) is bigger than critical (1.96). This means that university image has an $n$ effect on prospective student interest. This result gives an empirical evidence that a better image of a university will lead to a higher interest of prospective students. This also explains that university image with its available educational service, environment nature, provision of information, behavior and relationship between school communities become a reference for prospective students in choosing a private university.

\subsection{Effect of Prospective student Trust on Student Intention}

Based on test results presented in Table $4.7 \mathrm{t}$ statistic of student trust (2.287) is bigger that $\mathrm{t}$ critical (1.96), meaning that prospective student trust has an effect on the satisfaction of accounting information. The results of this study provide empirical evidence that a higher trust given by prospective students to a university will increase the interest of prospective students. This means that trust variable $t$ with Shared value 
indicator, communication, and behavior control significantly influence prospective student interest. Student interest will arise if the university can fulfill their needs and it can influence them to choose the university. This result is consistent with research by [32] that stated that trust has a positive effect on interest.

Based on test results presented in Table $4.7 \mathrm{t}$ statistic of prospective student trust which is moderated by word of mouth (3.467) is bigger than critical(1.96), meaning that prospective student trust which is moderated by word of mouth has an effect on prospective student interest .The study provides empirical evidence that a prospective student trust supported by word of mouth will positively enhance student interest. This result is supported by [33] that stated that positive word-of-mouth has a moderating effect on customer trust and customer purchase intention.

\section{References}

(1) Anderson, J.C. and Narus, J.A. (1990), "A model of distributor firm and manufacturer firm working partnerships?', Journal of Marketing, Vol. 54, pp. 42-58.

(2) Arndt, J. (1967), Word of Mouth Advertising: A Review of the Literature, Advertising ResearchFederation, New York, NY.

(3) Berry, L.L. (2002), "Relationship marketing of servicesperspectives from 1983 and 2000', Journal of Relationship Marketing, Vol. 1 No. 1, pp. 59-77.

(4) Berry, L.L. and Parasuraman, A. (1991), Marketing Service - Competing through Quality, The Free Press,New York, NY.

(5) Bickart, B. and Schindler, R.M. (2001), "Internet forums as influential sources of consumer information', Journal of Interactive Marketing, Vol. 15 No. 3, pp. 31-40.

(6) Burke, P.J. and Stets, J.E. (1999), "Trust and commitment through self-verification', Social Psychology Quarterly, Vol. 62 No. 4, pp. 347-60.

(7) Buttle, F.A. (1997), "I heard it through the grapevine: issues in referral marketing", Proceedings of the 5th International Colloquium School of Management, Cranfield University.

(8) Buttle, F.A. (1998), "Word-of-mouth: understanding and managing referral marketing', Journal of Strategic Marketing, Vol. 6 No. 3, pp. 241-54.

(9) Chen, S.C. (2003), "The factors affecting insurance customer repurchase will - relationship marketing view', Master's degree thesis, Institute of Department of Business Administration, Chaoyang Universityof Technology, Wufong Township.

(10) Chen, Y.S., Wu, H.P. and Chiou, W.J. (2007), “The effect of trust in the relationships between business images and purchase intentions', Journal of St John's University, Vol. 24, pp. 111-26.

(11) Chiou, H. (2003), Social and Behavioral Science Quantification Research and Statistical Analysis, 2nd ed., Wu-Nan Press, Taipei.

(12) Chueh, K.J. (2004), "The impact of internet anonymity, Company image, and relationship quality on electronic word-of-mouth: the online game as the example', Master's degree thesis, Institute of Department of Business Administration, National Chung Hsing University, Taichung.

(13) Crosby, L.A., Evans, K.R. and Cowles, D. (1990), "Relationship quality in services selling:an interpersonal influence perspective', Journal of Marketing, Vol. 54, pp. 68-81.

(14) Day, G.S. (2000), 'Management market relationships', Journal of the Academy of Marketing Science, Vol. 28 No. 1, p. 24.

(15) Derbaix, C. and Vanhamme, J. (2003), “Inducing wordof-mouth by eliciting surprise: a pilot investigation', Journal of Economic Psychology, Vol. 24, pp. 99-116.

(16) Dodds, B.W., Monroe, K.B. and Grewal, D. (1991), "Effect of price, brand, and store information on buyers product evaluation', Journal of Marketing Research, Vol. 28 No. 3, pp. 307-19.

(17) Dowling, G.R. (1986), "Managing your Company image', Industrial Marketing Management, Vol. 15, pp. 109-15.

(18) Downloaded by DIPONEGORO UNIVERSITY At 16:57 07 December 2015 (PT)

(19) Duhan, D.F., Johnson, S.D., Wilcox, J.B. and Harrell, G.D. (1997), "Influences on consumer use of word-ofmouth recommendation sources', Journal of Academy of Marketing Science, Vol. 25 No. 4,pp. 283-95.

(20) Engel, J.F., Blackwell, R.D. and Miniard, P.W. (2001), Consumer Behavior, South-Western, Division of Thomson Learning, Cincinatti, OH. VOL. 65 NO. 32010 j TOURISM REVIEWj PAGE 31

(21) Flavia'n, C., Guinalı'u, M. and Torres, E. (2005), “The influence of Company image on consumer trust: a comparative analysis in traditional versus internet banking', Internet Research, Vol. 15 No. 4,pp. 447-71.

(22) Garbarino, E. and Johnson, M.S. (1999), "The different roles of satisfaction, trust, and commitment in customer relationships', Journal of Marketing, Vol. 63 2, April, pp. 70-87.

(23) Geiger, S. and Martin, S. (1999), "The internet as a relationship marketing tool - some evidence fromIrish companies', Irish Marketing Review, Vol. 12 No. 2, pp. 24-36.

(24) Gelb, B. and Johnson, M. (1995), "Word-of-mouth communication: causes and consequences', Journal of Health Care Marketing, Vol. 15 No. 3, pp. 54-8.

(25) Gronroos, C. (1994), "From marketing mix to relationship marketing: towards a paradigm shift in marketing', Management Decision, Vol. 32 No. 2, pp. 4-15.

(26) Guielford, J.P. (1965), Fundamental Statistics in Psychology and Education, McGraw-Hill, New York, NY.

(27) Hair, J.F., Black, W.C., Barry, J.B. \& Anderson, R.E. 2010. Multivariate Data Analysis: A Global Perspective. Seven Edition. Pearson: Singapura. 
(28) Hair, J.F., Black, W.C., Barry, J.B. \& Anderson, R.E. 2010. Multivariate Data Analysis: A Global Perspective. Seven Edition. Pearson: Singapura.

(29) Imam, Ghozali. 2006.. "Structural Equation Modeling, Metode Alternatif Dengan Partial Least Squares (PLS)" Universitas Diponegoro.

(30) Imam, Ghozali. 2006."Structural Equation Modeling, An Alternative Method with Partial Least Squares (PLS)"."Structural Equation Modeling, Metode Alternatif Dengan Partial Least Squares (PLS)" Universitas Diponegoro.

(31) Kartajaya, H. 2004. On Brand. Bandung: Mizan Media Utama.

(32) Kartajaya, H. 2004. On Brand. Bandung: Mizan Media Utama.
(33) Kasali, Rheland. (2003). Manajemen Public Relations. Jakarta. Grafiti.

(34) Keller, Kevin Lane, 2003. Strategic brand management: building, measuring,and managing brand equity. New York:Prentice Hall

(35) Keller, Kevin Lane, 2003. Strategic brand management: building, measuring, and managing brand equity. New York:Prentice Hall

(36) Zeithaml, V.A. (1988), “'Consumer perceptions of price, quality and value: a means-end model and synthesis of evidence', Journal of Marketing, Vol. 52 No. 3, pp. 222. 